\title{
Microfluidic Approaches and Methods Enabling Extracellular Vesicle Isolation for Cancer Diagnostics
}

\author{
Premanshu Kumar Singh ${ }^{1}$, Aarti Patel ${ }^{2}$, Anastasia Kaffenes ${ }^{3}$, Catherine Hord ${ }^{4}$, Delaney Kesterson ${ }^{4}$ \\ and Shaurya Prakash 1,5,* \\ 1 Department of Mechanical and Aerospace Engineering, College of Engineering, The Ohio State University, \\ Columbus, OH 43210, USA; singh.1651@osu.edu \\ 2 Department of Biomedical Engineering, College of Engineering, The Ohio State University, \\ Columbus, OH 43210, USA; patel.4097@osu.edu \\ 3 Department of Neuroscience, College of Arts and Sciences and College of Medicine, The Ohio State \\ University, Columbus, OH 43210, USA; kaffenes.1@osu.edu \\ 4 Center for Life Sciences Education, The Ohio State University, Columbus, OH 43210, USA; \\ hord.63@osu.edu (C.H.); kesterson.18@osu.edu (D.K.) \\ 5 Comprehensive Cancer Center, The Ohio State University, Columbus, OH 43210, USA \\ * Correspondence: prakash.31@osu.edu; Tel.: +1-614-688-4045
}

check for

updates

Citation: Singh, P.K.; Patel, A.;

Kaffenes, A.; Hord, C.; Kesterson, D.; Prakash, S. Microfluidic Approaches and Methods Enabling Extracellular Vesicle Isolation for Cancer

Diagnostics. Micromachines 2022, 13, 139. https://doi.org/10.3390/

mi13010139

Academic Editors: Xiaolin Chen and Jie Xu

Received: 15 December 2021

Accepted: 14 January 2022

Published: 16 January 2022

Publisher's Note: MDPI stays neutral with regard to jurisdictional claims in published maps and institutional affiliations.

Copyright: () 2022 by the authors. Licensee MDPI, Basel, Switzerland. This article is an open access article distributed under the terms and conditions of the Creative Commons Attribution (CC BY) license (https:// creativecommons.org/licenses/by/ $4.0 /)$.

\begin{abstract}
Advances in cancer research over the past half-century have clearly determined the molecular origins of the disease. Central to the use of molecular signatures for continued progress, including rapid, reliable, and early diagnosis is the use of biomarkers. Specifically, extracellular vesicles as biomarker cargo holders have generated significant interest. However, the isolation, purification, and subsequent analysis of these extracellular vesicles remain a challenge. Technological advances driven by microfluidics-enabled devices have made the challenges for isolation of extracellular vesicles an emerging area of research with significant possibilities for use in clinical settings enabling point-ofcare diagnostics for cancer. In this article, we present a tutorial review of the existing microfluidic technologies for cancer diagnostics with a focus on extracellular vesicle isolation methods.
\end{abstract}

Keywords: extracellular vesicles; exosome; microfluidics; cancer diagnosis

\section{Introduction}

The National Cancer Institute (NCI) defines cancer as a disease in which some of the body's cells grow uncontrollably and spread to other parts of the body. Solid tumors can spread to other anatomical locations, recur in the same location post-treatment, or invade nearby tissue. It is now generally believed that cancer is caused by changes to genes that control cell function, especially impacting processes on how cells grow and divide. There are more than 100 types of cancer, often named for the organs or tissues where these tumors may form. The treatment of cancer requires reliable diagnostics to identify the type and extent of the disease.

The accepted gold standard for cancer diagnosis is through a tissue biopsy [1]. However, recent reports have noted the multitude of challenges presented by tissue biopsies as these are invasive procedures that may lead to patient discomfort and increase the risk of cancer seeding other locations when carried out on inaccessible tumors [2]. A tissue biopsy provides a snapshot of a tissue sample at a given time with only a small fraction of the suspected tumor extracted for a biopsy [3]. Subsequently, an even smaller fraction of tissue is analyzed, and therefore the tissue biopsy may not accurately portray intratumor spatial heterogeneity [4-6].

With continued advances in cancer research [7-9], multiregion genetic analysis of consecutive tumors has shown that each tumor presents diverse, spatially distinct mutations with varied phenotypes within the same tumor [6]. Moreover, a single tumor biopsy sample 
may be inadequate to develop personalized medicine strategies due to the variations in tumor properties $[10,11]$. Complexity, diversity, and varied physiological locations for solid tumors [12] lead to additional limitations such as not having enough tumor tissue available for biopsy or not being able to monitor intratumor temporal heterogeneity or metastatic sites [5,13].

As a complementary method to tissue biopsies, a liquid biopsy is an investigation and analysis of biofluids to identify biomarkers in a patient fluid sample for cancer diagnosis, prognosis, and monitoring [14,15]. Liquid biopsies rely on the constituent materials in biofluids representing the tumor state. Consequently, the main analytical targets in liquid biopsies include extracellular vesicles (EVs), circulating nucleic acids, and circulating tumor cells (CTCs) [16]. Liquid biopsies may provide additional potential benefits due to relatively low cost $[17,18]$, being minimally invasive $[19,20]$, and providing the opportunity for detailed molecular profiles of tumor-derived materials shed into a variety of biofluids, such as blood [21], urine [22], saliva [23], and cerebrospinal fluid (CSF) [24,25].

Microfluidics is the development and study of devices and systems with operational dimensions in the $1-100 \mu \mathrm{m}$ range for the manipulation of small $\left(10^{-9}-10^{-18} \mathrm{~L}\right)$ quantities of fluids [26]. As technological progress in microfluidics [27] has continued over the past 20 years, the use of analyzing patient biofluids (e.g., blood, urine, or saliva) containing particles sized from $10 \mathrm{~nm}$ to $100 \mu \mathrm{m}$ as a diagnostic tool for cancer has also found major interest [28-30]. Microfluidic devices have been extensively used for the isolation, enrichment, and detection of large biomolecules like DNA [31] and proteins [32], as well as extracellular vesicles [33], circulating tumor cells (CTCs) [34], and circulating nucleic acids [35]. The compact nature of microfluidic devices helps conduct multiple unit operations on a single device with integrated functioning [36,37]. These devices are compact and portable and, therefore, suitable for point-of-care (PoC) diagnostics [38,39].

The growing interest in developing microfluidics-enabled technologies for exploiting the advantages offered by liquid biopsies is seen in Figure 1, as reflected by the rapid growth of peer-reviewed publications in this area. A search for the keywords "liquid biopsy" in December 2021 in Elsevier's database Scopus yields 11,918 articles published since 2010. The largest numbers were published most recently in 2020 (2182) and 2021 (2426). Adding the keyword "microfluidics" shows 2520 publications in the last decade, with 2020 showing 537 articles published and the partial year for 2021 already showing 699 articles published, compared to fewer than 20 articles published 10 years ago.

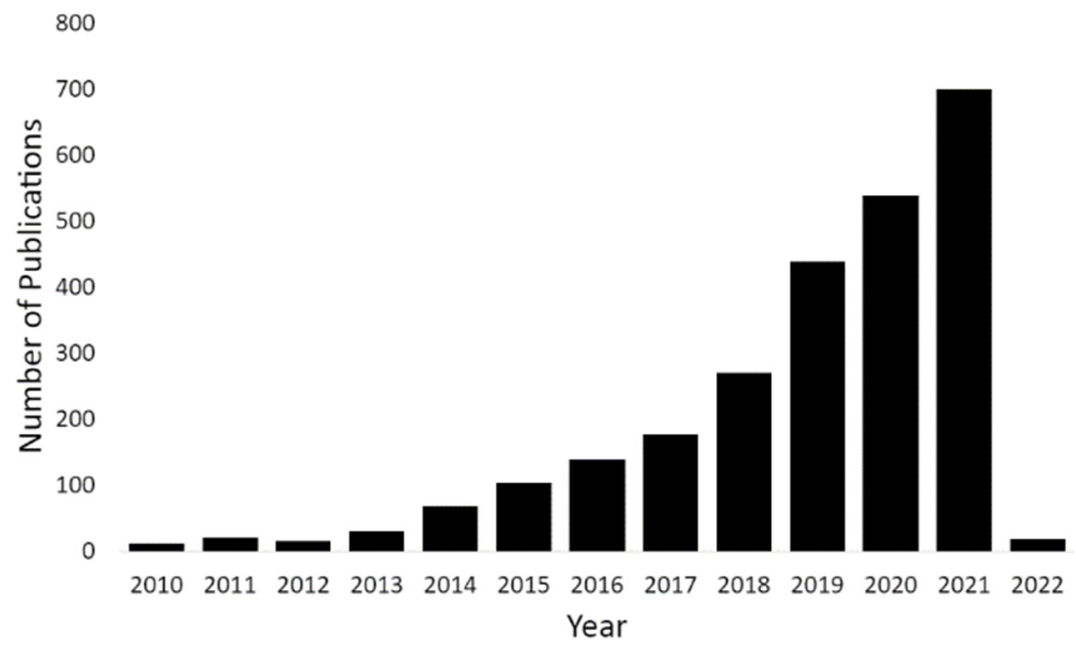

Figure 1. Number of papers published over the last decade with keywords "microfluidics" and "liquid biopsy". Data obtained from Scopus using a keyword search in December 2021.

Therefore, the purpose of this article is to reach a broad audience of science and engineering researchers developing new microscale flow-based technologies for cancer diagnostics. This review article focuses on microfluidic and nanofluidic devices and the 
various technological approaches implemented through these devices for liquid biopsies with an emphasis on methods and approaches used for isolation, detection, and analysis of extracellular vesicles (EVs) from biofluids. The article describes a few conventional isolation techniques to provide a contrast to the emerging microfluidics technologies, with references cited in Section 3 providing the readers with an opportunity to consider conventional EV isolation methods in further detail. Therefore, this article is structured with an overview of the conventional EV isolation techniques followed by a discussion of various microfluidic technologies using phenomena like immunoaffinity, filtration, acoustofluidics, inertial microfluidics, and electrokinetics. It should be noted that there are no standardized definitions to compare the isolation efficiency of a microfluidic device and subsequent sample purity. Each study defines parameters relevant to the study for quantifying the performance of the respective devices; hence, in this review, we have included the definition of parameters as noted by the respective authors. We believe the field as a whole can benefit from a standardized definition and generation of comparative metrics, allowing the comparison of various microfluidic technologies.

\section{Importance of Extracellular Vesicles}

Extracellular vesicles (EVs) are a heterogeneous collection of membrane-bound carriers released by nearly all cells $[40,41]$. EVs carry complex cargoes, including proteins, lipids, DNA, miRNA, and nucleic acids [42,43]. Previously, it was assumed that EVs were a mechanism to discard nonfunctional cellular components [44,45]. Based on size, composition, and origin, EVs can be classified into two main categories: exosomes and microvesicles [3]. Exosomes are small EVs $(30-100 \mathrm{~nm})$ and are secreted into the extracellular environment via fusion of multivesicular endosomes with the cell surface, whereas microvesicles are larger EVs (100-1000 nm) that are released by the outward budding and cleavage of the plasma membrane as shown in Figure 2 [46]. Exosomes are of particular importance because these particles have been shown to contain biomarkers, such as nucleic acids and proteins, from their origin cell that have been shown to influence intercellular communication [47]. Further work is needed to evaluate the cargo and roles for microvesicles, especially the large EVs greater than $500 \mathrm{~nm}$ in size.

\begin{tabular}{|c|c|c|}
\hline & Exosomes & Microvesicles \\
\hline Origin & Endosome & Plasma membrane \\
\hline Size & $50-150 \mathrm{~nm}$ & $50-500 \mathrm{~nm}$ (up to $1 \mu \mathrm{m})$ \\
\hline $\begin{array}{l}\text { Other names } \\
\text { (according to their } \\
\text { origin, } \\
\text { size and morphology) }\end{array}$ & $\begin{array}{l}\text { - Prostasomes } \\
\text { - Tolerosomes } \\
\text { - Dexosomes } \\
\text { - Nanovesicles } \\
\text { - Exosome-like vesicles } \\
\text { and others }\end{array}$ & $\begin{array}{l}\text { - Microparticles } \\
\text { - Blebbing vesicles } \\
\text { - Shedding vesicles } \\
\text { - Oncosomes } \\
\text { - ARRMs } \\
\text { - Migrasomes } \\
\text { - Neurospheres } \\
\text { - Apoptotic bodies }\end{array}$ \\
\hline
\end{tabular}

Figure 2. Extracellular vesicles are heterogeneous membrane-bound vesicles that are characterized based on size and origin. Microvesicles are typically larger (100-1000 nm), whereas exosomes are smaller (50-150 nm). There are a variety of terms used to describe extracellular vesicles, with emerging consensus on defining them as small or large EVs. Reprinted by permission from Springer Nature Customer Service Centre GmbH: Springer Nature, Nature Reviews Molecular Cell Biology [46].

Through modulation of intercellular communication, EVs also play a role in tumorigenesis [48-50]. The tumor microenvironment, which includes blood vessels, fibroblasts, immune cells, and cancer cells, regulates tumor resistance, progression, and metastasis, and all cells within the microenvironment can release EVs [51]. Additionally, researchers have discovered that tumor cells may release more EVs than normal cells [3,52]. Normal 
or noncancer cells can internalize EVs via receptor-mediated endocytosis, phagocytosis, macropinocytosis, or fusion with the membrane, as shown in Figure 3, resulting in the subsequent changes in the recipient cell [46]. Therefore, tumor-derived exosomes can travel to distal premetastatic target cells and promote metastatic tumor growth by initiating stromal support of tumor angiogenesis, decreasing the antitumor immune response, and enhancing the proliferation of tumor cells [40,53-56].

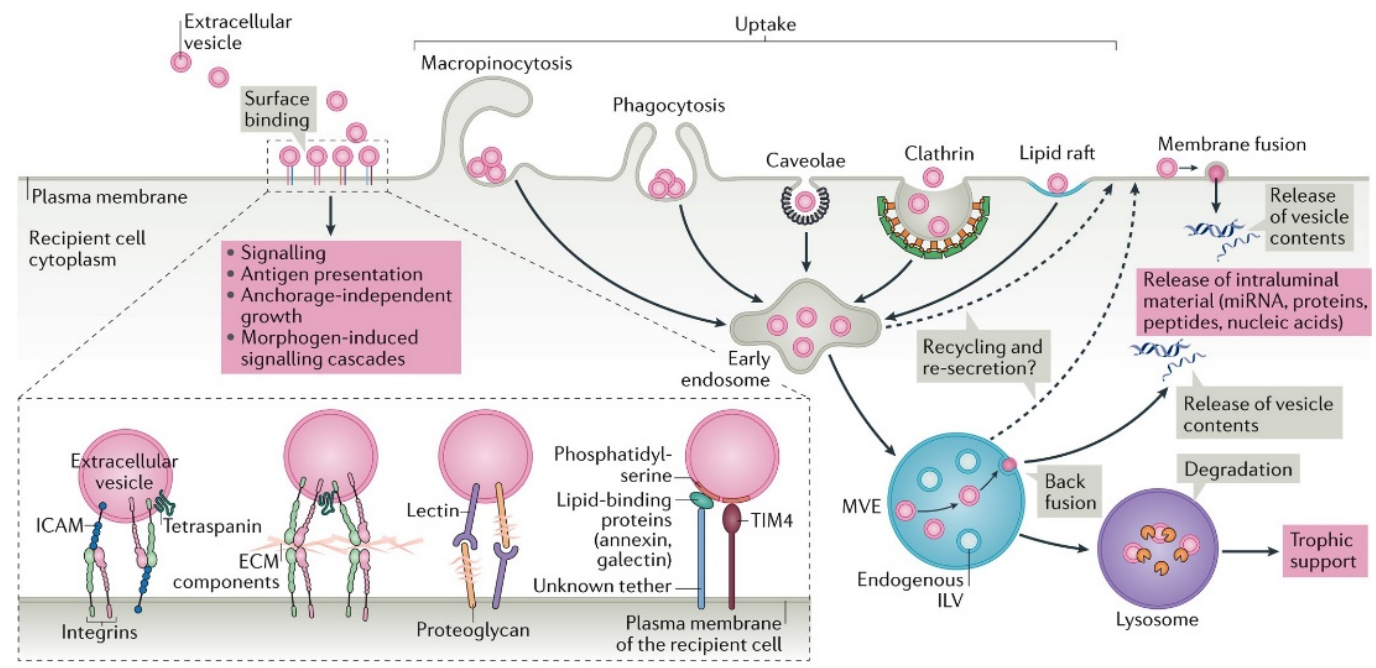

Figure 3. Visual representation of receptor-mediated endocytosis, macropinocytosis, phagocytosis, and membrane fusion of EVs into recipient cells as a means of intercellular communication. Reprinted by permission from Springer Nature Customer Service Centre GmbH: Springer Nature, Nature Reviews Molecular Cell Biology [46].

For example, in 2018, Guisti et al. demonstrated intercellular EV modulation in vitro by treating normal human dermal fibroblasts (NHDF) with EVs derived from human ovarian cancer cells, SKOV3 (more aggressive) and CABA I (less aggressive) [57]. During treatment, the morphology of fibroblasts transitioned to resemble cancer-associated fibroblasts (CAFs), and this transition was later confirmed by marker analysis found in CAFs, such as $\alpha$-SMA and FSP-1 [57]. These CAFs were able to influence the proliferation, motility, and invasiveness of surrounding endothelial, tumor, and fibroblast cells, confirming that EVs from ovarian cancer cells cause normal fibroblast cells to behave like CAFs, and these simulated CAFs may alter the behavior of surrounding cells [57]. Similarly, Webber et al. revealed that TGF $\beta 1$ expressed on the surface of exosomes derived from prostate cancer cells (PCa) was necessary for the differentiation from normal to tumor-promoting stroma in vivo [58]. In another in vitro experiment, PCa-derived exosomes promoted cell migration, attenuated apoptosis, and escalated cancer cell growth [59].

It is important to note that while the EV cargo often presents a snapshot of the host cell $[47,60]$, the composition of EVs can be different from that of origin cells due to selective cargo sorting [61]. Despite the potential diagnostic and prognostic utility of EVs, the practical relevance of using EVs for routine analysis is limited, as the methodologies required for $\mathrm{EV}$ isolation are either time-consuming, provide low yields of EV cargo, or add substantial cost to diagnostic processes [61].

\section{Conventional Isolation Techniques}

Isolation of EVs is briefly described in this section with a particular focus on centrifugationbased methods, ultrafiltration, and polymer-based precipitation methods that have been the cornerstone methodologies for the isolation and detection of EVs.

Table 1 presents a summary of methods for the isolation of cancer-relevant materials using conventional techniques. 
Table 1. Table summarizing conventional isolation techniques for EVs.

\begin{tabular}{|c|c|c|c|c|c|}
\hline Isolation Method & $\begin{array}{l}\text { Operating } \\
\text { Principle }\end{array}$ & Advantages & Study & $\begin{array}{l}\text { Isolation } \\
\text { Efficiency }\end{array}$ & Throughput \\
\hline Centrifugation & $\begin{array}{l}\text { Spinning results in } \\
\text { separation and } \\
\text { pellet formation }\end{array}$ & High purity & $\begin{array}{l}\text { Use of multiple } \\
\text { centrifugation cycles for } \\
\text { exosome enrichment from } \\
\text { human serum [62] }\end{array}$ & - & - \\
\hline Size exclusion & $\begin{array}{l}\text { Particles separated } \\
\text { based on size }\end{array}$ & $\begin{array}{l}\text { Minimal impact on } \\
\text { size and features }\end{array}$ & $\begin{array}{l}\text { Quality and efficiency } \\
\text { assessment of qEV using } \\
\text { nano-flow cytometry [63] }\end{array}$ & $67.7 \pm 13.1 \%[63]$ & - \\
\hline $\begin{array}{l}\text { Polymer-based } \\
\text { precipitation }\end{array}$ & $\begin{array}{l}\text { Precipitation of } \\
\text { lower solubility } \\
\text { components of } \\
\text { sample out of } \\
\text { solution }\end{array}$ & $\begin{array}{l}\text { Time efficient; } \\
\text { requires minimal } \\
\text { equipment }\end{array}$ & $\begin{array}{c}\text { Quality and efficiency } \\
\text { assessment of ExoQuick } \\
\text { isolation kit using } \\
\text { nano-flow cytometry [63] }\end{array}$ & $\sim 82 \%$ [63] & - \\
\hline
\end{tabular}

\subsection{Centrifugation-Based Techniques}

One of the more common techniques for the isolation of extracellular vesicles (EVs) is ultracentrifugation. In this technique, a sample from cell-cultured media or serum [64] is spun at high speeds, causing a separation of the components to form a pellet containing the majority of the EVs. The literature is inconsistent in defining a precise speed for ultracentrifugation compared to other centrifugation methods [65]. However, generally for ultracentrifugation, spin speeds with accelerations to $2 \times 10^{5} \mathrm{~g}$ have previously been reported [66-69]. To purify the pelleted samples, it may be necessary to spin the sample multiple times [66]. In standard centrifugation processes, speeds with acceleration of $4 \times 10^{4} \mathrm{~g}$ have been reported [62]. In differential ultracentrifugation, the sample is spun in a sequence of increasing speeds, commonly starting with accelerations of 300-400 $g$, then $2000 \mathrm{~g}$, and reaching 10,000 $g$ [69].

However, excessive spinning may result in damage to the EVs [66]. On the other hand, inadequate centrifugation may result in a high level of impurities in the EV sample due to coisolation, which occurs when other components in the liquid samples such as extravesicular protein complexes or aggregates, lipoprotein particles, and other contaminants [70] are incorporated into the isolated EV sample [67]. Impure samples complicate the analysis of EVs as it is difficult to determine whether characteristics are directly related to the EVs or the other co-isolated components [67]. Moreover, past results have also shown that extended centrifugation beyond $70 \mathrm{~min}$ can result in higher yields of RNA and protein from the EVs, but duration beyond four hours may result in the presence of excess protein [65]. Consequently, determining the optimal centrifugation conditions for the spin duration is important [65].

Previous reports have evaluated the efficiency of multiple cycles of centrifugation at $4 \times 10^{4} \mathrm{~g}$ versus ultracentrifugation at $11 \times 10^{4} \mathrm{~g}$ in the isolation of EVs, and the results have indicated that five cycles at either acceleration may be required to obtain a suitable sample with the two methods generating similar results [62]. Others have examined the biofluid viscosity dependence on the efficiency of the EV isolation. The results suggest that sample dilution prior to ultracentrifugation may be advantageous [71]. In a comparison of isolation methods, when ultracentrifugation was used in isolation from samples in cell culture media, particle concentrations of $6.20 \times 10^{8}, 6.33 \times 10^{7}$, and $9.17 \times 10^{6}$ particles $/ \mathrm{mL}$ were obtained, respectively, over three samples in a concentration gradient [64]. In the same comparison, the use of ultracentrifugation in serum samples produced particle concentrations of $6.35 \times 10^{9}, 2.22 \times 10^{9}$, and $1.23 \times 10^{9}$ particles $/ \mathrm{mL}$ over three samples [64]. In a separate study comparing EV isolation methods, the purity obtained through differential ultracentrifugation was found to be $78.2 \pm 0.6 \%$, where purity is based on the particle counts before and after treatment of Triton X-100 (used as a nonionic surfactant for lysing the phospholipid bilayer of EVs) [63]. The drawbacks of using 
ultracentrifugation were noted throughout this section with the primary ones relating to high cost, low EV yield, and long run times; however, this technique may yield higher protein purity [64].

\subsection{Size Exclusion}

Size exclusion chromatography is another method of EV isolation in which particles are separated based on size. This method can be applied to a wide variety of biofluids, including cell culture media, blood plasma and serum, urine, milk, saliva, nasal lavage, synovial fluid, cerebrospinal fluids, ascites, and tear fluids [72]. A sample is loaded into a column often containing cross-linked but porous agarose beads [72]. Larger molecules pass through the column as they are too large to enter the pores, while smaller components enter the pores and take longer to elute [69]. EVs are larger than smaller molecules [68] and therefore elute faster. One advantage of using size exclusion chromatography is that it has minimal impact on EV properties [72,73], with the sample purity, scalability, and reproducibility offered by this method being considered positives [69]. Work of Tian et al. on size exclusion chromatography performed using $\mathrm{qEV}$ columns shows purity of $28.1 \pm 0.8 \%$ [63] with twenty minutes to process one sample [69,74]. They lysed the phospholipid bilayer of EVs using non-ionic surfactant Triton X-100 and used the particle counts before and after treatment of Triton X-100 as a measure of EV preparations purity [63]. However, this method may not be effective in isolating particles of similar sizes or EVs from lipoproteins [72,75].

\subsection{Polymer-Based Precipitation Methods}

In polymer-based precipitation methods, reagents are added to a conditioned culture medium, causing the lower-solubility components of the sample to precipitate out of the solution [76]. The sample is then spun with accelerations of approximately $1500 \mathrm{~g}$ [77] to obtain a collection of EVs [69]. This creates a pellet similar to that obtained through the use of ultracentrifugation but avoids the higher centrifugal forces that may damage EVs [78]. These methods have an incubation time from $30 \mathrm{~min}$ to $12 \mathrm{~h}$ [78]. One disadvantage of this method lies in the fact that co-isolation may occur [78,79]. Additionally, the reagents added are often difficult to remove, and these reagents can interfere with the subsequent analysis of EVs $[78,80]$. Protein concentration and particle numbers are commonly used for the quantification of exosomes. Generally, exosome purity is defined as the ratio of particle number to protein concentration [81]. Moreover, the purity of these samples may be lower than that obtained by other methods such as ultracentrifugation due to protein contamination [64]. For example, components of plasma such as fibrinogen may interfere with sample purity, but additional steps, including treatment with thrombin and centrifugation, may eliminate this interference [63]. Additionally, serum albumin and apolipoprotein E were found in samples isolated through the use of polymer-based precipitation methods [82]. The purity of two different types of polymer precipitation was assessed, and one produced a purity of $5.3 \pm 2.6 \%$, and the other had a purity of $18.5 \pm 1.5 \%$ [63]. Precipitation methods may be favorable due to the preservation of biological activity found in EVs and the minimal equipment required [76]. However, the commercial kits used in polymer-based precipitation methods use supplies costing $4 \mathrm{USD} / \mathrm{mL}$ of the sample [76] and total cost reaching USD 50 per test. To minimize expenses, lower-cost precipitation reagents such as polyethylene glycol may be used [83]. When used alongside ultracentrifugation, these methods may result in higher yields than other conventional isolation techniques [84]. In fact, particle concentrations obtained through polymer-based precipitation methods maybe two to four orders of magnitude larger than those obtained through ultracentrifugation only [63].

\section{Microfluidic-Based Devices for Extracellular Vesicle Isolation}

While much progress has occurred over time in cancer diagnostic methods, the use of EVs remains underutilized, as articulated in the previous sections. The challenges in the 
isolation and capture of EVs prompted the development of microfluidic systems to separate EVs in a relatively short time (10-200 $\mathrm{min})$ with small sample volumes (100 $\mu \mathrm{L}-8 \mathrm{~mL})$ [30]. It is worth noting that cancer diagnostic methods deploying microfluidics and nanofluidics constitute a vast area of research, with circulating cancer cells, cell-free DNA, and other biomarkers also being researched extensively. However, as the focus of this work is on EVs, in the sections to follow we describe only a subset of this broader field, as many other reviews are available for other biomaterials used in cancer diagnostics [5,15,16,85-89].

Table 2 presents a summary of methods for the isolation of cancer-relevant materials using microfluidic technologies.

Table 2. Table summarizing several microfluidic techniques for isolation of EVs.

\begin{tabular}{|c|c|c|c|c|c|}
\hline $\begin{array}{l}\text { Isolation } \\
\text { Method }\end{array}$ & $\begin{array}{l}\text { Operating } \\
\text { Principle }\end{array}$ & Advantages & Study & $\begin{array}{l}\text { Isolation } \\
\text { Efficiency }\end{array}$ & Throughput \\
\hline \multirow{4}{*}{ Immunoaffinity } & \multirow{4}{*}{$\begin{array}{l}\text { Interactions } \\
\text { between } \\
\text { antibodies and } \\
\text { antigens }\end{array}$} & \multirow{4}{*}{ High specificity } & $\begin{array}{l}{ }^{\mathrm{HB}} \text { EXO-chip for purifying } \\
\text { tumor-derived exosomes } \\
\text { and establishing miRNA } \\
\text { signature in pancreatic } \\
\text { cancer with } \\
\text { GPC1+exosomes as } \\
\text { biomarkers [90] }\end{array}$ & $\sim 75 \%$ [90] & - \\
\hline & & & $\begin{array}{l}\text { Using CD-63-1 aptamer } \\
\text { for the isolation of EVs } \\
(50-150 \mathrm{~nm}) \text { from CD-63 } \\
\text { positive tumor samples } \\
\text { [91] }\end{array}$ & - & - \\
\hline & & & $\begin{array}{l}\text { OncoBean (DUO) using } \\
\text { melanoma-specific } \\
\text { antibodies MCAM and } \\
\text { MCSP for exosome } \\
\text { isolation [92] }\end{array}$ & - & - \\
\hline & & & $\begin{array}{l}\text { Immunoaffinity-based } \\
\text { isolation of melanoma } \\
\text { cell-derived exosomes } \\
\text { from plasma of patients } \\
\text { with melanoma with } \\
\text { CSPG4-specific mAb } \\
763.74 \text { as biomarker [93] }\end{array}$ & - & - \\
\hline \multirow{3}{*}{ Filtration } & \multirow{3}{*}{$\begin{array}{l}\text { Difference in } \\
\text { particle size } \\
\text { population }\end{array}$} & \multirow{3}{*}{$\begin{array}{l}\text { No need for } \\
\text { external actuation; } \\
\text { easy to use }\end{array}$} & $\begin{array}{c}\text { Isolation of bladder cancer } \\
\text { EVs from urine samples } \\
\text { using integrated } \\
\text { double-filtration device } \\
{[94]}\end{array}$ & $74.2 \%$ [94] & - \\
\hline & & & $\begin{array}{l}\text { Isolation of exosome-like } \\
\text { lipid vesicles via a ciliated } \\
\text { micropillar device [95] }\end{array}$ & $\begin{array}{c}60 \% \text { (83 nm lipid } \\
\text { vesicles), } 45 \% \\
\text { (120 nm lipid } \\
\text { vesicles) [95] }\end{array}$ & $3 \mu \mathrm{L} / \min [95]$ \\
\hline & & & $\begin{array}{l}\text { Isolation and capture of } \\
\text { EVs from liposarcoma } \\
\text { cell-conditioned media } \\
\text { (LCCM) and } \\
\text { dedifferentiated } \\
\text { liposarcoma patient } \\
\text { serum, with MDM2 and } \\
\text { CD-63 as biomarkers [96] }\end{array}$ & $\begin{array}{c}\text { 76\% (LCCM), } \\
36 \% \\
\text { (dedifferentiated } \\
\text { liposarcoma } \\
\text { patient serum) } \\
\text { [96] }\end{array}$ & $10 \mu \mathrm{L} / \min [96]$ \\
\hline
\end{tabular}


Table 2. Cont.

\begin{tabular}{|c|c|c|c|c|c|}
\hline $\begin{array}{l}\text { Isolation } \\
\text { Method }\end{array}$ & $\begin{array}{l}\text { Operating } \\
\text { Principle }\end{array}$ & Advantages & Study & $\begin{array}{l}\text { Isolation } \\
\text { Efficiency }\end{array}$ & Throughput \\
\hline \multirow{5}{*}{ Acoustofluidics } & \multirow{5}{*}{ Acoustic waves } & \multirow{5}{*}{$\begin{array}{l}\text { Biocompatibility, } \\
\text { versatility, } \\
\text { precision, } \\
\text { flexibility }\end{array}$} & $\begin{array}{c}\text { Isolation of salivary } \\
\text { exosomes from Human } \\
\text { papilloma viral (HPV)- } \\
\text { associated oropharyngeal } \\
\text { cancer } \\
\text { patients with HPV DNA } \\
\text { as biomarker [97] }\end{array}$ & - & - \\
\hline & & & $\begin{array}{l}\text { Isolating exosomes } \\
\text { directly from undiluted } \\
\text { human blood [98] }\end{array}$ & $82 \%$ [98] & $4 \mu \mathrm{L} / \min [98]$ \\
\hline & & & $\begin{array}{c}\text { Nanoparticle enrichment } \\
\text { and separation using } \\
\text { acoustic centrifugation } \\
\text { [99] }\end{array}$ & - & - \\
\hline & & & $\begin{array}{l}\text { Acoustic trapping for the } \\
\text { enrichment of EVs from } \\
\text { cell culture conditioned } \\
\text { media, urine, and blood } \\
\text { plasma from healthy } \\
\text { volunteers [100] }\end{array}$ & - & $\begin{array}{c}10 \mu \mathrm{L} / \min \\
{[100]}\end{array}$ \\
\hline & & & $\begin{array}{l}\text { Separation of exosomes } \\
\text { using acoustic nanofilter } \\
\text { system [101] }\end{array}$ & $>90 \%[101]$ & - \\
\hline Viscoelastic flow & $\begin{array}{l}\text { Imbalance of } \\
\text { normal forces in a } \\
\text { non-Newtonian } \\
\text { medium }\end{array}$ & $\begin{array}{l}\text { Ease of use, no } \\
\text { requirements for } \\
\text { external actuation, } \\
\text { robust } \\
\text { performance once } \\
\text { operational } \\
\text { parameters are } \\
\text { optimized }\end{array}$ & $\begin{array}{l}\text { Separation of exosomes } \\
\text { from cell culture media } \\
\text { and serum of } \\
\text { adenocarcinomic human } \\
\text { alveolar basal epithelial } \\
\text { cells [102] }\end{array}$ & $>80 \%$ [102] & $200 \mu \mathrm{L} / \mathrm{h}[102]$ \\
\hline Electrokinetics & $\begin{array}{l}\text { Charge of the } \\
\text { particle and } \\
\text { electrolyte }\end{array}$ & $\begin{array}{l}\text { Strong actuation } \\
\text { force due to linear } \\
\text { scaling law }\end{array}$ & $\begin{array}{l}\text { On-chip microcapillary } \\
\text { electrophoresis for } \\
\text { separation of human } \\
\text { breast cancer derived } \\
\text { exosomes [103] }\end{array}$ & - & - \\
\hline
\end{tabular}

\subsection{Isolation Based on Immunoaffinity}

In immunoaffinity-based separation, molecules are selectively captured due to specific interactions between antibodies and antigens [104]. The stationary phase often consists of antibodies that have been immobilized and target specific antigens within the sample and isolate portions containing this specific antigen [105]. The implementation of this approach for microfluidic devices usually requires functionalization of the walls of a microfluidics device with immobilized antibodies [104]. Therefore, surface preparation for functionalization $[106,107]$ plays an important role in tethering antibodies [96]. Physicochemical interactions leading to eventual binding or capture of antigens at the immobilized antibody site include hydrogen bonding, coulombic interactions, Van der Waals interactions, and hydrophobic interactions [104].

A high throughput implementation of immunoaffinity separation is the ${ }^{\mathrm{HB}} \mathrm{EXO}-\mathrm{Chip}$, a device featuring eight channels and a herringbone design that allows for the separation of EVs 30-150 nm in diameter from plasma [90]. The capture efficiency was calculated by allowing 50 million exosomes per milliliter of PBS solution to flow into the device, 
followed by measuring the concentration of nanoparticles before and after the sample run through the ${ }^{\mathrm{HB}} \mathrm{EXO}-\mathrm{Chip}$ to determine the number of particles captured [90]. The ${ }^{\mathrm{HB}} \mathrm{EXO}-\mathrm{Chip}$ has demonstrated a 75\% capture efficiency of tumor-derived exosomes from plasma [90]. Other devices reported for isolating EVs 50-150 nm in diameter have targeted specific cancer biomarkers [91]. For example, a CD-63-1 aptamer was designed for the isolation of EVs 50-150 nm in diameter from tumor samples which are positive for CD-63, considered to be a biomarker in certain types of cancers, including breast cancer [91]. The OncoBean chip (Figure 4) uses biotin-avidin chemistry to facilitate the collection of EVs [108]. Kang et al. reported on the dual-utilization OncoBean (DUO) by targeting separation of EVs using melanoma-specific antibodies melanoma cell adhesion molecule (MCAM) and melanoma-associated chondroitin sulfate proteoglycan (MCSP) [92]. In another implementation of immunoaffinity with microfluidics, devices use magnetic beads coated with antibodies [109]. Additionally, specific biomarkers can also be used to isolate specific EVs with diameters 40-120 nm [110]. For example, Sharma et al. used melanomaspecific biomarkers such as mAb 763.74 (specific for CSPG4 epitope) for the isolation of EVs (30-150 nm) from melanoma cells [93].
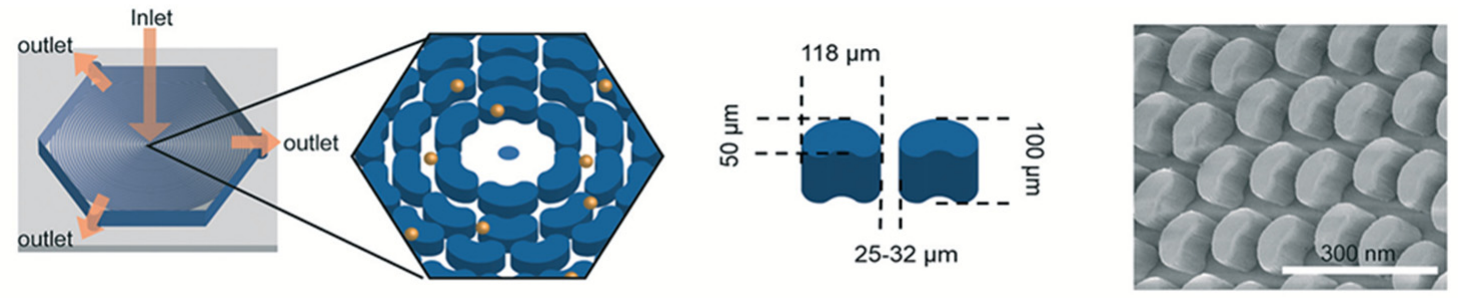

Extracelluar Vesicles

NeutrAvidin

Desthiobiotin anti-CD63

Biotin
Captured by Dethiobiontin-conjugated anti-CD63

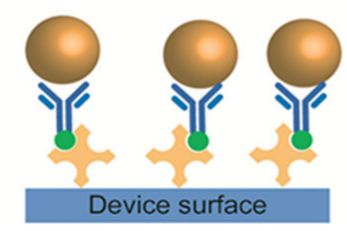

Released by biotin

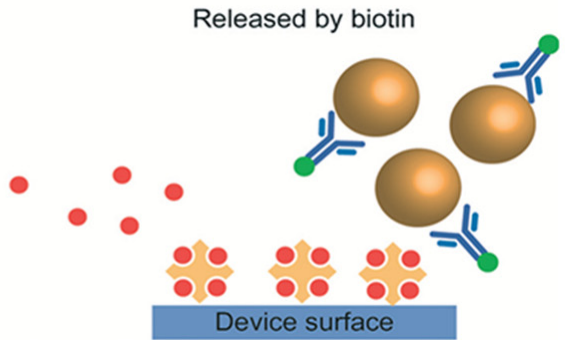

Figure 4. Schematic showing features and functionality of the OncoBean Chip. Width, length, and height of posts were 50,118, and $100 \mu \mathrm{m}$, respectively, with an interpost distance of 25-32 $\mu \mathrm{m}$. NeutrAvidin is used to coat the surface of the device, which helps in the incorporation of desthiobiotinconjugated antibodies required for recognition of surface markers of EVs. Biotin is used for the release of the desthiobiotin-antibody-EV complex and effectively allowing for collection of EVs. Reprinted from [108] with permission from the Royal Society of Chemistry.

\subsection{Isolation Based on Size}

\subsubsection{Filtration}

Filtration within microfluidic devices is a passive, size-based isolation technique that utilizes a physical barrier to isolate desired EVs. The filters can be microfabricated, or existing filtration media can be integrated within microfluidic devices [111,112]. Filtration systems provide advantages over other microfluidic mechanisms due to their inherent simplicity with minimal requirements to label the desired EV products with fluorescent tags for imaging prior to separation. Some isolation devices utilize common labeling methods like fluorescent tagging to image EVs using fluorescent microscopy, though such techniques can disrupt the entrapment ability by altering the size, shape, and functionality of the molecules to which they are attached. Label-free isolation methods used in filtration devices contribute to higher entrapment efficiency while maintaining the functionality of EVs so that they can be examined after isolation [111]. However, the main challenge for these EV isolation methods is the lack of specificity in isolating particles [96]. 
Many implementations of EV isolation using size-based filtration have been reported. For example, Liang et al. fabricated an integrated double-filtration device that isolated EVs from bladder cancer patients [94]. The device consisted of two polycarbonate membranes with 30 and $200 \mathrm{~nm}$ pores, which enabled the isolation of EVs within the 30-200 nm size range, and after filtration of the urine samples, the EVs were then detected and quantified using enzyme-linked immunoassay (ELISA) [94]. The isolation efficiency was defined as the ratio of the number of EVs isolated and the number of EVs in the input sample. In comparison against healthy control urine samples, the samples from bladder cancer participants demonstrated a significant increase of EVs present in the urine with $74.2 \%$ isolation and entrapment efficiency [94]. To examine its diagnostic effectiveness, the authors determined the device's sensitivity and specificity, where sensitivity refers to the ELISA chip's ability to correctly identify cancer-related EVs, and specificity refers to the chip's ability to accurately distinguish non-cancer-related particles. Overall, the device demonstrated $81.3 \%$ sensitivity with a specificity of $90 \%$ [94], thus suggesting clinical feasibility for the use of this device for cancer diagnostics. Another device of interest-a ciliated micropillar-based filtration device developed by Wang et al.—successfully isolated exosome-like lipid vesicles from a $30 \mu \mathrm{L}$ injection sample with high efficiency in $10 \mathrm{~min}$ [95]. Smaller, $83 \mathrm{~nm}$ lipid vesicles were trapped and recovered within the device with $\sim 60 \%$ retention, while larger, $120 \mathrm{~nm}$ lipid vesicles observed a 15\% retention decrease [95]. Casadei et al. integrated the tasks of size-based separation in a crossflow arrangement with the CD-63 antibody immunoaffinitybased capture of liposarcoma-derived EVs in a single micro-nanofluidic device (Figure 5) and achieved $\sim 76 \%$ and $\sim 32 \%$ EV recovery for liposarcoma cell-conditioned media and dedifferentiated liposarcoma patient serum, respectively, when compared against ultracentrifugation [96]. They also reported a significant advance over existing state-of-the-art techniques with a five-fold enhancement in the quantity of liposarcoma-relevant EV-DNA obtained in $30 \mathrm{~min}$ [96].

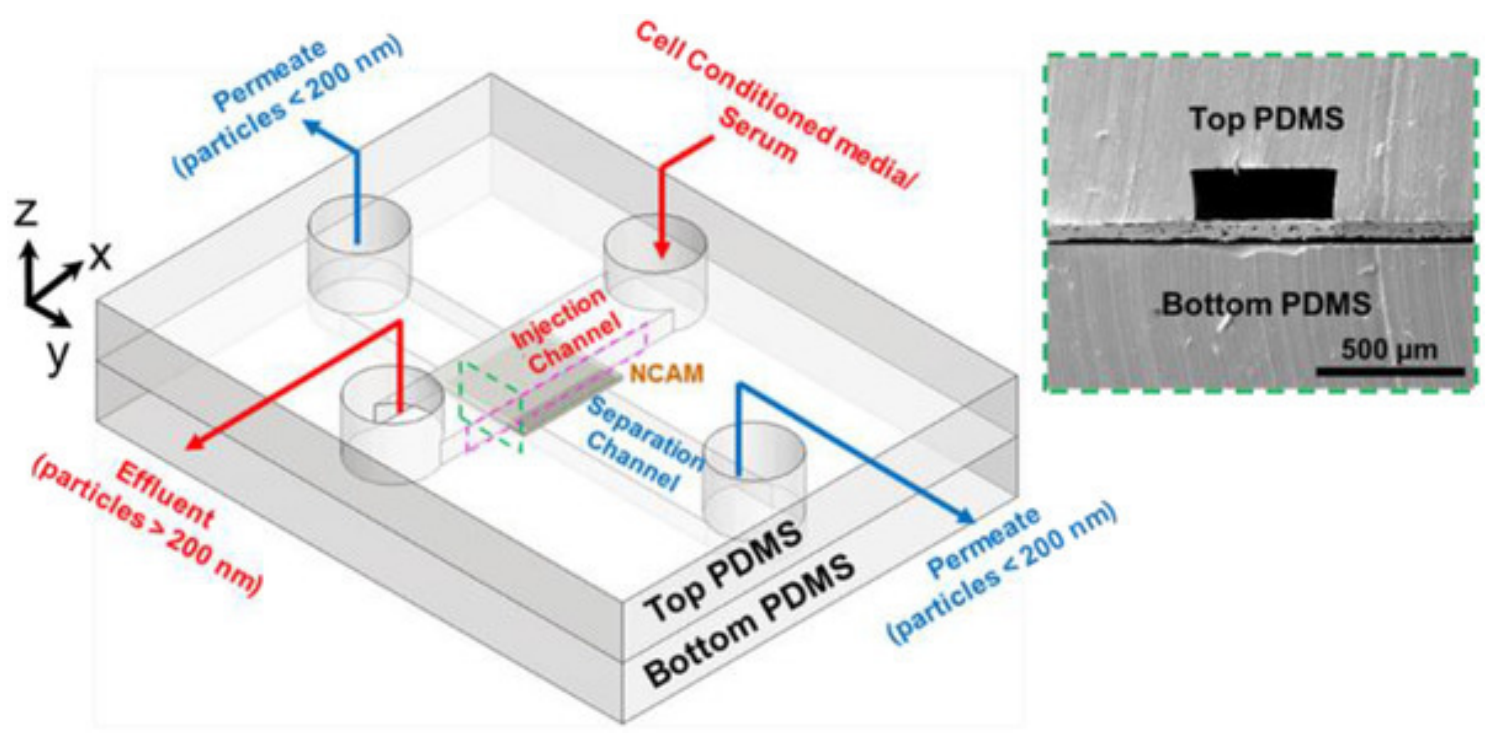

Figure 5. Schematic of Casadei et al. microfluidic filtration device consisting of perpendicular injection and separation channels separated by a nanocapillary array membrane (NCAM). Figure used with permission from [96].

\subsubsection{Acoustofluidics}

Acoustofluidics are microfluidic devices that integrate microfluidics and wave acoustics. These devices use acoustic (or sound) waves for particle patterning, transport, focusing, separation, sorting, and enrichment of particles [113]. These devices use either surface acoustic waves (SAWs) or bulk acoustic waves (BAWs) [114]. Acoustic waves which propagate along the surface of elastic material are called SAWs [115]. In contrast, BAW are standing waves that are generated within the volume of the elastic medium and propagate 
in the interior of the device [114]. Acoustic radiation and acoustic streaming are the two main forces that govern the separation of particles which depend on the particle size and material properties, including density and compressibility. Acoustic radiation forces are experienced by a particle when it interacts with an acoustic wave and is proportional to the particle volume, whereas acoustic streaming arises in the fluid by the absorption of high acoustic oscillations and induces the size-dependent Stokes drag force on the particles suspended in the fluid [116,117]. Acoustofluidic devices provide various advantages for EV isolation because these devices can be operated label-free with minimal contact and use of reagents $[114,118]$.

Wang et al. developed an acoustofluidic device for the detection of human papillomavirusassociated oropharyngeal cancer (HPV-OPC) using human papilloma viral (HPV) DNA in the whole saliva as a diagnostic means for HPV-POC [97]. Their device consisted of a PDMS microchannel $100 \mu \mathrm{m}$ in height and $800 \mu \mathrm{m}$ in width bonded with two pairs of interdigitated transducers (IDTs) generating SAWs at frequencies of $20 \mathrm{MHz}$ and $40 \mathrm{MHz}$ [97]. The two IDTs were at an angle with respect to the microchannel. The output resulted in isolated EVs in the 30-150 nm diameter range [97]. Their results showed an insignificant effect of variable viscosity (from 1.10 to $2.30 \mathrm{mPa} . \mathrm{s}$ ) of saliva samples on the number of isolated EVs [97]. In a similar device, Wu et al. exhibited the isolation of exosomes from whole blood [98]. Gu et al. proposed an acoustofluidic centrifuge system capable of nanoparticle transport, concentration, and separation [99]. Their device consists of a circular PDMS containment ring with a pair of tilted IDTs surrounding the circular PDMS [99]. Acoustic radiation force and drag force produced by the SAWs generate a rotational vortex field in the sample droplet, which forced the particles to follow a helical trajectory, resulting in their rapid concentration to the center of the droplet [99].

$\mathrm{Ku}$ et al. used acoustic trapping for the enrichment of EVs from urine, cell-cultured conditioned media, and blood from healthy volunteers [100]. Their device output sample carried EVs varying from exosomes to microvesicles in size and included observable levels of intravesicular microRNAs and further confirmed no impact of acoustic waves on the integrity or miRNA content of the trapped vesicles [100]. Lee et al. developed a nanofilter based on acoustofluidics for the separation of extracellular microvesicles and isolated exosomes of diameter less than $200 \mathrm{~nm}$ from erythrocyte-derived vesicles from stored blood units and cell-conditioned media with a separation yield of $>90 \%$ [101].

\subsubsection{Inertial Microfluidics}

An emerging class of devices examines the size-dependent isolation of neutrally buoyant particles via lateral migration in a non-Newtonian fluid $[102,119,120]$. Such devices utilize the non-Newtonian viscoelastic properties of blood or saliva to enhance simple isolation capabilities while minimizing pre-isolation modifications [119,121]. Unlike Newtonian fluids, particles in viscoelastic flows are subject to an imbalance of normal stresses that drives their lateral migration, such as the inward driving force of fluid elasticity, the outward force of shear thinning, and particle motion [119,120]. Larger particles demonstrate a tendency to migrate toward the center of the channel at a faster rate, while smaller particles remain along the side walls of the device [102,121]. Such microfluidic devices are advantageous as they do not require externally applied fields (e.g., electric, magnetic, or acoustic), which simplifies device design and fabrication [102].

Exploiting fluid inertia and viscoelastic properties has been successful for CTC isolation. However, their use for isolating EVs is limited as with nanoscale particles such as EVs, the inertial lift forces [122] are much smaller, and the standard approaches of these inertial microfluidics may not work. However, recent advances in combined electrokinetic and Poiseuille flow have shown the ability to manipulate dielectric particles in Newtonian flows $[123,124]$, with the application to EV isolation remaining an open question. Though, for non-Newtonian fluids, Liu et al. reported isolating exosomes from other large EVs in a diluted poly-(oxyethylene) (PEO) solution that served to enhance the viscoelasticity of the solution and generate the lift forces responsible for EV isolation from smaller particles 
(Figure 6) [102]. Nanoparticle tracking analysis (NTA) was used to determine the recovery rate and purity of the separation by measuring the size distributions of the initial and processed samples [102]. The device demonstrated a greater than $90 \%$ separation purity with more than $80 \%$ recovery [102].

(a)

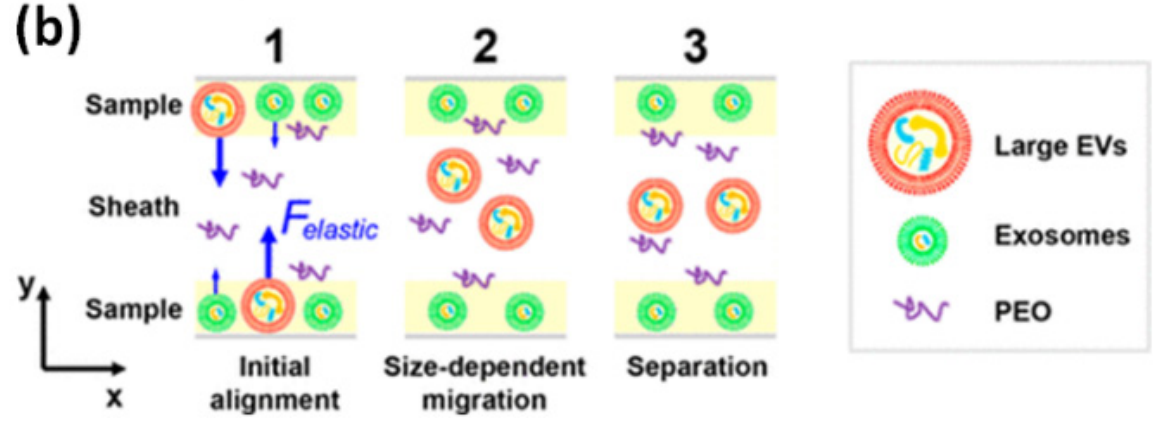

Figure 6. (a) Schematic of the microfluidic chip used by Liu et al. [102] for exosome separation from large EVs. The chip consists of two inlets and three outlets where EVs are collected in the center outlet while exosomes exit the two peripheral outlets. (b) Illustration of exosome isolation in a viscoelastic medium via elastic lift force (blue arrows) to migrate larger EVs toward the center of the channel while maintaining lateral exosome flow along the side walls of the device. Reprinted with permission from Lui et al. [102]. Copyright 2017 American Chemical Society.

\subsection{Isolation Based on Electrokinetics}

The coupling of an applied electric field to fluid flow gives rise to electrokinetic flows [125]. There are a variety of electrokinetic phenomena [126] that have found use in microfluidics, such as electrophoresis [127], electromigration [128], electroosmosis, dielectrophoresis [129], streaming potential, and sedimentation potential.

Electrokinetic phenomena have also been used for the isolation and detection of EVs [130-134]. Aïzel et al. used a radial geometry in a micro-nanofluidic device for the enrichment of viruses and exosomes [135]. On application of an electric field across $100 \mathrm{~nm}$ deep radial channels, they observed concentration and repulsion at the cathodic and anodic part, respectively, achieving an enrichment factor of up to 800 for $50 \mathrm{~nm}$ nanoparticles within $1 \mathrm{~h}$ [135]. Dey et al. used a symmetric AC electric field [136] in a convergingdiverging channel to analyze the trapping of charged microparticles [137]. They studied the trapping mechanisms at low $(\leq 100 \mathrm{~Hz}$ ) and intermediate (from $\sim 100 \mathrm{~Hz}$ to $100 \mathrm{kHz}$ ) frequencies and reported a significant dominance of linear electrokinetic phenomena, including electrophoresis and electroosmosis, over the effect of positive electrophoresis in the concentration profile of the analyte which was trapped [137].

A previous report by Kato et al. showed the use of on-chip microcapillary electrophoresis $(\mu \mathrm{CE})$ and laser dark-field microscopy to demonstrate the correlation between the average $\zeta$ potentials of exosomes extracted from six different types of human cell cul- 
tures (normal breast epithelial cells (MCF10A), breast cancer cells (MDA-MB-231 [MM231] and MDA-MB-231-luc-D3H2LN cells [MM231LN]), normal prostate epithelial cells (PNT2), and prostate cancer cells (PC-3 and PC-3M-luc-C6 [PC-3ML])) in serum-free media and their cells of origin [138]. They reported a negative shift in the $\zeta$ potential distribution of tumor-derived exosomes compared to exosomes derived from nontumor cells [138]. Extending the study for the label-free prescreening of prostate cancer using the same $\mu \mathrm{CE}$ system [138], Akagi et al. analyzed the $\zeta$ potential of prostate cancer exosomes and reported a larger $\zeta$ potential for cancer-derived exosomes [139]. Akagi et al. also integrated their $\mu \mathrm{CE}$ system [138] with immunoaffinity for the differential protein expression profiling of individual EVs for the detection of overexpression of CD-63 glycoproteins on EVs [103]. They used EVs collected from the culture supernatant of MDA-MB-231 human breast cancer cells and anti-human CD63 antibody and immunoglobulin G (IgG) as EV markers [103].

Devices based on microfluidic techniques for EV isolation typically offer faster separation times with smaller sample volumes compared to conventional EV isolation methods. Tables 1 and 2 give an overview and comparison of the discussed conventional and microfluidic EV isolation methods. As noted throughout the review, each method offers advantages and disadvantages. At present, there are no standard methods to compare microfluidic device performance and conventional methods. Specific definitions arise from individual studies based on samples used, equipment, personnel, cost, and resource availability. There is also a gap in the literature in terms of heterogeneity in EV isolation techniques with no common definitions or protocol for reporting and defining efficiency parameters, including characterization of EV size, composition, and purity across cancer and methodology types.

\section{Summary and Conclusions}

This tutorial review noted the progress in the use of microfluidics-enabled devices for the isolation of extracellular vesicles from a variety of biofluids. The article also summarized comparisons to existing technologies. Clearly, microfluidics can play an important role in developing translational solutions with impact in point-of-care diagnostics for cancer. The survey of publications indicates robust interest in continued device development and technology progress in new and innovative approaches that use a variety of physical phenomena for isolation and analysis of extracellular vesicles.

Author Contributions: Conceptualization, P.K.S. and A.P.; writing-original draft preparation, P.K.S., A.P., A.K., C.H., D.K.; writing-review and editing, S.P. and P.K.S.; supervision, S.P.; funding acquisition, S.P. All authors have read and agreed to the published version of the manuscript.

Funding: This work was supported in part by the National Institutes of Health under Grant R01HL141941 (Shaurya Prakash).

Conflicts of Interest: The authors declare no conflict of interest.

\section{References}

1. Diamantis, A.; Magiorkinis, E.; Koutselini, H. Fine-needle aspiration (FNA) biopsy: Historical aspects. Folia Histochem. Cytobiol 2009, 47, 191-197. [CrossRef]

2. Robertson, E.G.; Baxter, G. Tumour seeding following percutaneous needle biopsy: The real story! Clin. Radiol. 2011, 66, 1007-1014. [CrossRef]

3. Lu, J.; Pang, J.; Chen, Y.; Dong, Q.; Sheng, J.; Luo, Y.; Lu, Y.; Lin, B.; Liu, T. Application of Microfluidic Chips in Separation and Analysis of Extracellular Vesicles in Liquid Biopsy for Cancer. Micromachines 2019, 10, 390. [CrossRef]

4. Vogelstein, B.; Papadopoulos, N.; Velculescu, V.E.; Zhou, S.; Diaz, L.A., Jr.; Kinzler, K.W. Cancer genome landscapes. Science 2013, 339, 1546-1558. [CrossRef]

5. Gerlinger, M.; Rowan, A.J.; Horswell, S.; Larkin, J.; Endesfelder, D.; Gronroos, E.; Martinez, P.; Matthews, N.; Stewart, A.; Tarpey, P.; et al. Intratumor Heterogeneity and Branched Evolution Revealed by Multiregion Sequencing. N. Engl. J. Med. 2012, 366, 883-892. [CrossRef] [PubMed]

6. Pasha, N.; Turner, N.C. Understanding and overcoming tumor heterogeneity in metastatic breast cancer treatment. Nat. Cancer 2021, 2, 680-692. [CrossRef] 
7. $\mathrm{Hu}, \mathrm{Z} . ; \mathrm{Li}, \mathrm{Z} . ; \mathrm{Ma}, \mathrm{Z}$; C Curtis, C. Multi-cancer analysis of clonality and the timing of systemic spread in paired primary tumors and metastases. Nat. Genet. 2020, 52, 701-708. [CrossRef] [PubMed]

8. Tellez-Gabriel, M.; Ory, B.; Lamoureux, F.; Heymann, M.-F.; Heymann, D. Tumour Heterogeneity: The Key Advantages of Single-Cell Analysis. Int. J. Mol. Sci. 2016, 17, 2142. [CrossRef]

9. Winkler, J.; Abisoye-Ogunniyan, A.; Metcalf, K.J.; Werb, Z. Concepts of extracellular matrix remodelling in tumour progression and metastasis. Nat. Commun. 2020, 11, 5120. [CrossRef]

10. Prakash, S.; Karnes, M.P.; Sequin, E.K.; West, J.D.; Hitchcock, C.L.; Nichols, S.D.; Bloomston, M.; Abdel-Misih, S.R.; Schmidt, C.R.; Martin, E.W., Jr.; et al. Ex vivo electrical impedance measurements on excised hepatic tissue from human patients with metastatic colorectal cancer. Physiol Meas 2015, 36, 315-328. [CrossRef] [PubMed]

11. Lochab, V.; Jones, T.H.; Alkandry, E.; West, J.D.; Abdel-Rahman, M.H.; Subramaniam, V.V.; Prakash, S. Evaluation of electrical properties of ex vivo human hepatic tissue with metastatic colorectal cancer. Physiol. Meas. 2020, 41, 085005. [CrossRef]

12. 40 Years of the War on Cancer. Science 2011, 331, 1540-1544. [CrossRef]

13. Mino-Kenudson, M. Cons: Can liquid biopsy replace tissue biopsy?-the US experience. Transl. Lung Cancer Res. 2016, 5, 424-427. [CrossRef]

14. Špilak, A.; Brachner, A.; Kegler, U.; Neuhaus, W.; Noehammer, C. Implications and pitfalls for cancer diagnostics exploiting extracellular vesicles. Adv. Drug Deliv. Rev. 2021, 175, 113819. [CrossRef]

15. Tadimety, A.; Closson, A.; Li, C.; Yi, S.; Shen, T.; Zhang, J.X.J. Advances in liquid biopsy on-chip for cancer management: Technologies, biomarkers, and clinical analysis. Crit. Rev. Clin. Lab. Sci. 2018, 55, 140-162. [CrossRef] [PubMed]

16. Vaidyanathan, R.; Soon, R.H.; Zhang, P.; Jiang, K.; Lim, C.T. Cancer diagnosis: From tumor to liquid biopsy and beyond. Lab A Chip 2019, 19, 11-34. [CrossRef] [PubMed]

17. Sánchez-Calderón, D.; Pedraza, A.; Mancera Urrego, C.; Mejía-Mejía, A.; Montealegre-Páez, A.L.; Perdomo, S. Analysis of the Cost-Effectiveness of Liquid Biopsy to Determine Treatment Change in Patients with Her2-Positive Advanced Breast Cancer in Colombia. Clin. Outcomes Res. 2020, 12, 115-122. [CrossRef]

18. Chen, M.; Zhao, H. Next-generation sequencing in liquid biopsy: Cancer screening and early detection. Hum. Genom. 2019, 13, 34. [CrossRef] [PubMed]

19. Bieńkowski, M.; Pęksa, R.; Popęda, M.; Kołaczkowska, M.; Frankiewicz, A.; Żaczek, A.J.; Gruchała, M.; Biernat, W.; Siondalski, P. Liquid biopsy for minimally invasive heart transplant monitoring: A pilot study. J. Clin. Pathol. 2020, 73, 507-510. [CrossRef]

20. Calandri, M.; Siravegna, G.; Yevich, S.M.; Stranieri, G.; Gazzera, C.; Kopetz, S.; Fonio, P.; Gupta, S.; Bardelli, A.; Veltri, A.; et al. Liquid biopsy, a paradigm shift in oncology: What interventional radiologists should know. Eur. Radiol. 2020, 30, 4496-4503. [CrossRef]

21. Liu, C.; Xiang, X.; Han, S.; Lim, H.Y.; Li, L.; Zhang, X.; Ma, Z.; Yang, L.; Guo, S.; Soo, R.; et al. Blood-based liquid biopsy: Insights into early detection and clinical management of lung cancer. Cancer Lett. 2022, 524, 91-102. [CrossRef]

22. Li, G.; Zhao, A.; Péoch, M.; Cottier, M.; Mottet, N. Detection of urinary cell-free miR-210 as a potential tool of liquid biopsy for clear cell renal cell carcinoma. Urol. Oncol. Semin. Orig. Investig. 2017, 35, 294-299. [CrossRef]

23. Tu, M.; Cheng, J.; Chen, Y.-L.; Jea, W.-C.; Chen, W.-L.; Chen, C.-J.; Ho, C.-L.; Huang, W.-L.; Lin, C.-C.; Su, W.-C.; et al. Electric Field-Induced Release and Measurement (EFIRM): Characterization and Technical Validation of a Novel Liquid Biopsy Platform in Plasma and Saliva. J. Mol. Diagn. 2020, 22, 1050-1062. [CrossRef]

24. Le Rhun, E.; Seoane, J.; Salzet, M.; Soffietti, R.; Weller, M. Liquid biopsies for diagnosing and monitoring primary tumors of the central nervous system. Cancer Lett. 2020, 480, 24-28. [CrossRef] [PubMed]

25. von Baumgarten, L.; Kumbrink, J.; Jung, A.; Reischer, A.; Flach, M.; Liebmann, S.; Metzeler, K.H.; Holch, J.W.; Niyazi, M.; Thon, N.; et al. Therapeutic management of neuro-oncologic patients-Potential relevance of CSF liquid biopsy. Theranostics 2020, 10, 856-866. [CrossRef] [PubMed]

26. Whitesides, G.M. The origins and the future of microfluidics. Nature 2006, 442, 368-373. [CrossRef] [PubMed]

27. Prakash, S.; Yeom, J. Chapter 2-Fundamentals for Microscale and Nanoscale Flows. In Nanofluidics and Microfluidics, Prakash, S., Yeom, J., Eds.; William Andrew Publishing: Norwich, NY, USA, 2014; pp. 9-38.

28. Yamamoto, K.; Ota, N.; Tanaka, Y. Nanofluidic Devices and Applications for Biological Analyses. Anal. Chem. 2021, 93, 332-349. [CrossRef] [PubMed]

29. Prakash, S.; Piruska, A.; Gatimu, E.N.; Bohn, P.W.; Sweedler, J.V.; Shannon, M.A. Nanofluidics: Systems and Applications. IEEE Sens. J. 2008, 8, 441-450. [CrossRef]

30. Convery, N.; Gadegaard, N. 30 years of microfluidics. Micro Nano Eng. 2019, 2, 76-91. [CrossRef]

31. Breadmore, M.C.; Wolfe, K.A.; Arcibal, I.G.; Leung, W.K.; Dickson, D.; Giordano, B.C.; Power, M.E.; Ferrance, J.P.; Feldman, S.H.; Norris, P.M.; et al. Microchip-Based Purification of DNA from Biological Samples. Anal. Chem. 2003, 75, 1880-1886. [CrossRef]

32. He, M.; Crow, J.; Roth, M.; Zeng, Y.; Godwin, A.K. Integrated immunoisolation and protein analysis of circulating exosomes using microfluidic technology. Lab A Chip 2014, 14, 3773-3780. [CrossRef] [PubMed]

33. Zhao, Z.; Yang, Y.; Zeng, Y.; He, M. A microfluidic ExoSearch chip for multiplexed exosome detection towards blood-based ovarian cancer diagnosis. Lab A Chip 2016, 16, 489-496. [CrossRef]

34. Kang, Y.-T.; Purcell, E.; Palacios-Rolston, C.; Lo, T.-W.; Ramnath, N.; Jolly, S.; Nagrath, S. Isolation and Profiling of Circulating Tumor-Associated Exosomes Using Extracellular Vesicular Lipid-Protein Binding Affinity Based Microfluidic Device. Small 2019, 15, 1903600. [CrossRef] [PubMed] 
35. Lamanda, A.; Lu, Y.; Gill, N.; Wong, P.K. An electrokinetic microdevice for isolation and quantification of circulating cell-free DNA from physiological samples. In Proceedings of the 2015 Transducers-2015 18th International Conference on Solid-State Sensors, Actuators and Microsystems (TRANSDUCERS), Anchorage, AK, USA, 21-25 June 2015; pp. 544-547.

36. Reyes, D.R.; Iossifidis, D.; Auroux, P.-A.; Manz, A. Micro Total Analysis Systems. 1. Introduction, Theory, and Technology. Anal. Chem. 2002, 74, 2623-2636. [CrossRef] [PubMed]

37. Auroux, P.-A.; Iossifidis, D.; Reyes, D.R.; Manz, A. Micro Total Analysis Systems. 2. Analytical Standard Operations and Applications. Anal. Chem. 2002, 74, 2637-2652. [CrossRef]

38. Nayak, S.; Blumenfeld, N.R.; Laksanasopin, T.; Sia, S.K. Point-of-Care Diagnostics: Recent Developments in a Connected Age Anal. Chem. 2017, 89, 102-123. [CrossRef] [PubMed]

39. Dincer, C.; Bruch, R.; Kling, A.; Dittrich, P.S.; Urban, G.A. Multiplexed Point-of-Care Testing—xPOCT. Trends Biotechnol. 2017, 35, 728-742. [CrossRef]

40. Oey, O.; Ghaffari, M.; Li, J.J.; Hosseini-Beheshti, E. Application of extracellular vesicles in the diagnosis and treatment of prostate cancer: Implications for clinical practice. Crit. Rev. Oncol. Hematol. 2021, 167, 103495. [CrossRef]

41. Iliescu, F.S.; Vrtačnik, D.; Neuzil, P.; Iliescu, C. Microfluidic Technology for Clinical Applications of Exosomes. Micromachines 2019, 10, 392. [CrossRef] [PubMed]

42. Maas, S.L.N.; Breakefield, X.O.; Weaver, A.M. Extracellular Vesicles: Unique Intercellular Delivery Vehicles. Membr. Biol. 2017, 27, 172-188. [CrossRef]

43. Raposo, G.; Stoorvogel, W. Extracellular vesicles: Exosomes, microvesicles, and friends. J. Cell Biol. 2013, 200, 373-383. [CrossRef]

44. Valadi, H.; Ekström, K.; Bossios, A.; Sjöstrand, M.; Lee, J.J.; Lötvall, J.O. Exosome-mediated transfer of mRNAs and microRNAs is a novel mechanism of genetic exchange between cells. Nat. Cell Biol. 2007, 9, 654-659. [CrossRef]

45. Skog, J.; Würdinger, T.; Van Rijn, S.; Meijer, D.H.; Gainche, L.; Curry, W.T., Jr.; Carter, B.S.; Krichevsky, A.S.; Breakefield, X.O. Glioblastoma microvesicles transport RNA and proteins that promote tumour growth and provide diagnostic biomarkers. Nat. Cell Biol. 2008, 10, 1470-1476. [CrossRef] [PubMed]

46. van Niel, G.; D'Angelo, G.; Raposo, G. Shedding light on the cell biology of extracellular vesicles. Nat. Rev. Mol. Cell Biol. 2018, 19, 213-228. [CrossRef]

47. Simons, M.; Raposo, G. Exosomes-vesicular carriers for intercellular communication. Curr. Opin. Cell Biol. 2009, 21, 575-581. [CrossRef] [PubMed]

48. Huang, Y.; Xu, M.; Jing, C.; Wu, X.; Chen, X.; Zhang, W. Extracellular vesicle-derived miR-320a targets ZC3H12B to inhibit tumorigenesis, invasion, and angiogenesis in ovarian cancer. Discov. Oncol. 2021, 12, 51. [CrossRef]

49. Melo, S.A.; Sugimoto, H.; O'Connell, J.T.; Kato, N.; Villanueva, A.; Vidal, A.; Qiu, L.; Vitkin, E.; Perelman, L.T.; Melo, C.A.; et al. Cancer exosomes perform cell-independent microRNA biogenesis and promote tumorigenesis. Cancer Cell 2014, 26, 707-721. [CrossRef]

50. Kalluri, R. The biology and function of exosomes in cancer. J. Clin. Investig. 2016, 126, 1208-1215. [CrossRef] [PubMed]

51. Azadi, S.; Aboulkheyr Es, H.; Kulasinghe, A.; Bordhan, P.; Ebrahimi Warkiani, M. Chapter Five-Application of microfluidic technology in cancer research and therapy. In Advances in Clinical Chemistry; Makowski, G.S., Ed.; Elsevier: Amsterdam, The Netherlands, 2020; Volume 99, pp. 193-235.

52. Xu, Y.; Zhang, Y.; Wang, L.; Zhao, R.; Qiao, Y.; Han, D.; Sun, Q.; Dong, N.; Liu, Y.; Wu, D.; et al. miR-200a targets Gelsolin: A novel mechanism regulating secretion of microvesicles in hepatocellular carcinoma cells. Oncol. Rep. 2017, 37, 2711-2719. [CrossRef] [PubMed]

53. Bebelman, M.P.; Smit, M.J.; Pegtel, D.M.; Baglio, S.R. Biogenesis and function of extracellular vesicles in cancer. Pharmacol. Ther 2018, 188, 1-11. [CrossRef]

54. Maacha, S.; Bhat, A.A.; Jimenez, L.; Raza, A.; Haris, M.; Uddin, S.; Grivel, J.-C. Extracellular vesicles-mediated intercellular communication: Roles in the tumor microenvironment and anti-cancer drug resistance. Mol. Cancer 2019, 18, 55. [CrossRef] [PubMed]

55. Mathieu, M.; Martin-Jaular, L.; Lavieu, G.; Théry, C. Specificities of secretion and uptake of exosomes and other extracellular vesicles for cell-to-cell communication. Nat. Cell Biol. 2019, 21, 9-17. [CrossRef]

56. Gonda, A.; Kabagwira, J.; Senthil, G.N.; Wall, N.R. Internalization of Exosomes through Receptor-Mediated Endocytosis. Mol. Cancer Res. 2019, 17, 337. [CrossRef]

57. Giusti, I.; Di Francesco, M.; D’Ascenzo, S.; Palmerini, M.G.; Macchiarelli, G.; Carta, G.; Dolo, V. Ovarian cancer-derived extracellular vesicles affect normal human fibroblast behavior. Cancer Biol. Ther. 2018, 19, 722-734. [CrossRef] [PubMed]

58. Webber, J.P.; Spary, L.K.; Sanders, A.J.; Chowdhury, R.; Jiang, W.G.; Steadman, R.; Wymant, J.; Jones, A.T.; Kynaston, H.; Mason, M.D.; et al. Differentiation of tumour-promoting stromal myofibroblasts by cancer exosomes. Oncogene 2015, 34, $290-302$. [CrossRef] [PubMed]

59. Hosseini-Beheshti, E.; Choi, W.; Weiswald, L.-B.; Kharmate, G.; Ghaffari, M.; Roshan-Moniri, M.; Hassona, M.D.; Chan, L.; Chin, M.Y.; Tai, I.T.; et al. Exosomes confer pro-survival signals to alter the phenotype of prostate cells in their surrounding environment. Oncotarget 2016, 7, 14639. [CrossRef]

60. van Niel, G.; Porto-Carreiro, I.; Simoes, S.; Raposo, G. Exosomes: A common pathway for a specialized function. J. Biochem. 2006, 140, 13-21. [CrossRef] [PubMed] 
61. Głuszko, A.; Szczepański, M.J.; Ludwig, N.; Mirza, S.M.; Olejarz, W. Exosomes in Cancer: Circulating Immune-Related Biomarkers. BioMed Res. Int. 2019, 2019, 1628029. [CrossRef] [PubMed]

62. Kim, J.; Tan, Z.; Lubman, D. Exosome enrichment of human serum using multiple cycles of centrifugation. Electrophoresis 2015, 36, 2017-2026. [CrossRef] [PubMed]

63. Tian, Y.; Gong, M.; Hu, Y.; Liu, H.; Zhang, W.; Zhang, M.; Hu, X.; Aubert, D.; Zhu, S.; Wu, L.; et al. Quality and efficiency assessment of six extracellular vesicle isolation methods by nano-flow cytometry. J. Extracell Vesicles 2019, 9, 1697028. [CrossRef]

64. Tang, Y.-T.; Huang, Y.-Y.; Zheng, L.; Qin, S.-H.; Xu, X.-P.; An, T.-X.; Xu, Y.; Qu, Y.-S.; Hu, X.-M.; Ping, B.-H.; et al. Comparison of isolation methods of exosomes and exosomal RNA from cell culture medium and serum. Int. J. Mol. Med 2017, 40, 834-844. [CrossRef] [PubMed]

65. Cvjetkovic, A.; Lötvall, J.; Lässer, C. The influence of rotor type and centrifugation time on the yield and purity of extracellular vesicles. J. Extracell Vesicles 2014, 3, 23111. [CrossRef] [PubMed]

66. Brennan, K.; Martin, K.; FitzGerald, S.P.; O' Sullivan, J.; Wu, Y.; Blanco, A.; Richardson, C.; McGee, M.M. A comparison of methods for the isolation and separation of extracellular vesicles from protein and lipid particles in human serum. Sci. Rep. 2020, 10,1-13. [CrossRef]

67. Webber, J.; Clayton, A. How pure are your vesicles? J. Extracell Vesicles 2013, 2, 19861. [CrossRef] [PubMed]

68. Monguió-Tortajada, M.; Gálvez-Montón, C.; Bayes-Genis, A.; Roura, S.; Borrás, F. Extracellular vesicle isolation methods: Rising impact of size-exclusion chromatography. Cell. Mol. Life Sci. 2019, 76, 2369-2382. [CrossRef] [PubMed]

69. Sidhom, K.; Obi, P.; Saleem, A. A Review of Exosomal Isolation Methods: Is Size Exclusion Chromatography the Best Option? Int. J. Mol. Sci. 2020, 21, 6466. [CrossRef] [PubMed]

70. Witwer, K.W.; Buzás, E.I.; Bemis, L.T.; Bora, A.; Lässer, C.; Lötvall, J.; Nolte-'t Hoen, E.N.; Piper, M.G.; Sivaraman, S.; Skog, J.; et al. Standardization of sample collection, isolation and analysis methods in extracellular vesicle research. J. Extracell Vesicles 2013, 2, 20360. [CrossRef]

71. Momen-Heravi, F.; Balaj, L.; Alian, S.; Trachtenberg, A.; Hochberg, F.; Skog, J.; Kuo, W. Impact of Biofluid Viscosity on Size and Sedimentation Efficiency of the Isolated Microvesicles. Front. Physiol. 2012, 3, 162. [CrossRef] [PubMed]

72. Liangsupree, T.; Multia, E.; Riekkola, M.-L. Modern isolation and separation techniques for extracellular vesicles. J. Chromatogr. A 2021, 1636, 461773. [CrossRef]

73. Gámez-Valero, A.; Monguió-Tortajada, M.; Carreras-Planella, L.; Franquesa, M.1.; Beyer, K.; Borràs, F.E. Size-Exclusion Chromatography-based isolation minimally alters Extracellular Vesicles' characteristics compared to precipitating agents. Sci. Rep. 2016, 6, 33641. [CrossRef] [PubMed]

74. Stranska, R.; Gysbrechts, L.; Wouters, J.; Vermeersch, P.; Bloch, K.; Dierickx, D.; Andrei, G.; Snoeck, R. Comparison of membrane affinity-based method with size-exclusion chromatography for isolation of exosome-like vesicles from human plasma. J. Transl. Med. 2018, 16, 1. [CrossRef] [PubMed]

75. Askeland, A.; Borup, A.; Østergaard, O.; Olsen, J.V.; Lund, S.M.; Christiansen, G.; Kristensen, S.R.; Heegaard, N.H.H.; Pedersen, S. Mass-Spectrometry Based Proteome Comparison of Extracellular Vesicle Isolation Methods: Comparison of ME-kit, Size-Exclusion Chromatography, and High-Speed Centrifugation. Biomedicines 2020, 8, 246. [CrossRef] [PubMed]

76. Niu, Z.; Pang, R.; Liu, W.; Li, Q.; Cheng, R.; Yeung, W. Polymer-based precipitation preserves biological activities of extracellular vesicles from an endometrial cell line. PLoS ONE 2017, 12, e0186534. [CrossRef] [PubMed]

77. Konoshenko, M.Y.; Lekchnov, E.A.; Vlassov, A.V.; Laktionov, P.P. Isolation of Extracellular Vesicles: General Methodologies and Latest Trends. BioMed Res. Int. 2018, 2018, 8545347. [CrossRef] [PubMed]

78. Brown, P.; Yin, H. Polymer-Based Purification of Extracellular Vesicles. Methods Mol. Biol. 2017, 1660, 91-103.

79. Taylor, D.D.; Shah, S. Methods of isolating extracellular vesicles impact down-stream analyses of their cargoes. Methods 2015, 87, 3-10. [CrossRef]

80. Taylor, D.D.; Zacharias, W.; Gercel-Taylor, C. Exosome isolation for proteomic analyses and RNA profiling. Methods Mol. Biol. 2011, 728, 235-246. [CrossRef] [PubMed]

81. Lobb, R.J.; Becker, M.; Wen, S.W.; Wong, C.S.; Wiegmans, A.P.; Leimgruber, A.; Möller, A. Optimized exosome isolation protocol for cell culture supernatant and human plasma. J. Extracell Vesicles 2015, 4, 27031. [CrossRef] [PubMed]

82. Van Deun, J.; Mestdagh, P.; Sormunen, R.; Cocquyt, V.; Vermaelen, K.; Vandesompele, J.; Bracke, M.; De Wever, O.; Hendrix, A. The impact of disparate isolation methods for extracellular vesicles on downstream RNA profiling. J. Extracell Vesicles 2014, 3, 24858. [CrossRef] [PubMed]

83. Andreu, Z.; Rivas, E.; Sanguino-Pascual, A.; Lamana, A.; Marazuela, M.; González-Alvaro, I.; Sánchez-Madrid, F.; de la Fuente, H.; Yáñez-Mó, M. Comparative analysis of EV isolation procedures for miRNAs detection in serum samples. J. Extracell Vesicles 2016, 5, 31655. [CrossRef] [PubMed]

84. Yamada, T.; Inoshima, Y.; Matsuda, T.; Ishiguro, N. Comparison of Methods for Isolating Exosomes from Bovine Milk. J. Vet. Med. Sci. 2012, 74, 1523-1525. [CrossRef] [PubMed]

85. Kahlert, C. Liquid Biopsy: Is There an Advantage to Analyzing Circulating Exosomal DNA Compared to cfDNA or Are They the Same? Cancer Res. 2019, 79, 2462. [CrossRef] [PubMed]

86. Corcoran, R.B.; Chabner, B.A. Application of Cell-free DNA Analysis to Cancer Treatment. N. Engl. J. Med. 2018, $379,1754-1765$. [CrossRef] [PubMed] 
87. Mouliere, F.; Chandrananda, D.; Piskorz Anna, M.; Moore Elizabeth, K.; Morris, J.; Ahlborn Lise, B.; Mair, R.; Goranova, T.; Marass, F.; Heider, K.; et al. Enhanced detection of circulating tumor DNA by fragment size analysis. Sci. Transl. Med. 2018, 10, eaat4921. [CrossRef] [PubMed]

88. van den Berg, M.M.J.; Krauskopf, J.; Ramaekers, J.G.; Kleinjans, J.C.S.; Prickaerts, J.; Briedé, J.J. Circulating microRNAs as potential biomarkers for psychiatric and neurodegenerative disorders. Prog. Neurobiol. 2020, 185, 101732. [CrossRef]

89. Lee, J.-S.; Park, S.S.; Lee, Y.K.; Norton, J.A.; Jeffrey, S.S. Liquid biopsy in pancreatic ductal adenocarcinoma: Current status of circulating tumor cells and circulating tumor DNA. Mol. Oncol. 2019, 13, 1623-1650. [CrossRef]

90. Zhang, Y.; Tong, X.; Yang, L.; Yin, R.; Li, Y.; Zeng, D.; Wang, X.; Deng, K. A herringbone mixer based microfluidic device HBEXO-chip for purifying tumor-derived exosomes and establishing miRNA signature in pancreatic cancer. Sens. Actuators $B$ Chem. 2021, 332, 129511. [CrossRef]

91. Song, Z.; Mao, J.; Barrero, R.A.; Wang, P.; Zhang, F.; Wang, T. Development of a CD63 Aptamer for Efficient Cancer Immunochemistry and Immunoaffinity-Based Exosome Isolation. Molecules 2020, 25, 5585. [CrossRef] [PubMed]

92. Kang, Y.-T.; Hadlock, T.; Lo, T.-W.; Purcell, E.; Mutukuri, A.; Fouladdel, S.; Raguera, M.D.S.; Fairbairn, H.; Murlidhar, V.; Durham, A.; et al. Dual-Isolation and Profiling of Circulating Tumor Cells and Cancer Exosomes from Blood Samples with Melanoma Using Immunoaffinity-Based Microfluidic Interfaces. Adv. Sci. 2020, 7, 2001581. [CrossRef] [PubMed]

93. Sharma, P.; Ludwig, S.; Muller, L.; Hong, C.S.; Kirkwood, J.M.; Ferrone, S.; Whiteside, T.L. Immunoaffinity-based isolation of melanoma cell-derived exosomes from plasma of patients with melanoma. J. Extracell Vesicles 2018, 7, 1435138. [CrossRef]

94. Liang, L.-G.; Sheng, Y.-F.; Zhou, S.; Inci, F.; Li, L.; Demirci, U.; Wang, S. An Integrated Double-Filtration Microfluidic Device for Detection of Extracellular Vesicles from Urine for Bladder Cancer Diagnosis. In Extracellular Vesicles: Methods and Protocols; Kuo, W.P., Jia, S., Eds.; Springer: New York, NY, USA, 2017; pp. 355-364.

95. Wang, Z.; Wu, H.-j.; Fine, D.; Schmulen, J.; Hu, Y.; Godin, B.; Zhang, J.X.J.; Liu, X. Ciliated micropillars for the microfluidic-based isolation of nanoscale lipid vesicles. Lab A Chip 2013, 13, 2879-2882. [CrossRef]

96. Casadei, L.; Choudhury, A.; Sarchet, P.; Mohana Sundaram, P.; Lopez, G.; Braggio, D.; Balakirsky, G.; Pollock, R.; Prakash, S Cross-flow microfiltration for isolation, selective capture and release of liposarcoma extracellular vesicles. J. Extracell Vesicles 2021, 10, e12062. [CrossRef] [PubMed]

97. Wang, Z.; Li, F.; Rufo, J.; Chen, C.; Yang, S.; Li, L.; Zhang, J.; Cheng, J.; Kim, Y.; Wu, M.; et al. Acoustofluidic Salivary Exosome Isolation: A Liquid Biopsy Compatible Approach for Human Papillomavirus-Associated Oropharyngeal Cancer Detection. J. Mol. Diagn. 2020, 22, 50-59. [CrossRef] [PubMed]

98. Wu, M.; Ouyang, Y.; Wang, Z.; Zhang, R.; Huang, P.H.; Chen, C.; Li, H.; Li, P.; Quinn, D.; Dao, M.; et al. Isolation of exosomes from whole blood by integrating acoustics and microfluidics. Proc. Natl. Acad. Sci. USA 2017, 114, 10584-10589. [CrossRef] [PubMed]

99. Gu, Y.; Chen, C.; Mao, Z.; Bachman, H.; Becker, R.; Rufo, J.; Wang, Z.; Zhang, P.; Mai, J.; Yang, S.; et al. Acoustofluidic centrifuge for nanoparticle enrichment and separation. Sci. Adv. 2021, 7, eabc0467. [CrossRef] [PubMed]

100. Ku, A.; Lim, H.C.; Evander, M.; Lilja, H.; Laurell, T.; Scheding, S.; Ceder, Y. Acoustic Enrichment of Extracellular Vesicles from Biological Fluids. Anal. Chem. 2018, 90, 8011-8019. [CrossRef] [PubMed]

101. Lee, K.; Shao, H.; Weissleder, R.; Lee, H. Acoustic Purification of Extracellular Microvesicles. ACS Nano 2015, 9, 2321-2327. [CrossRef]

102. Liu, C.; Guo, J.; Tian, F.; Yang, N.; Yan, F.; Ding, Y.; Wei, J.; Hu, G.; Nie, G.; Sun, J. Field-Free Isolation of Exosomes from Extracellular Vesicles by Microfluidic Viscoelastic Flows. ACS Nano 2017, 11, 6968-6976. [CrossRef] [PubMed]

103. Akagi, T.; Kato, K.; Kobayashi, M.; Kosaka, N.; Ochiya, T.; Ichiki, T. On-Chip Immunoelectrophoresis of Extracellular Vesicles Released from Human Breast Cancer Cells. PLoS ONE 2015, 10, e0123603. [CrossRef] [PubMed]

104. Peoples, M.C.; Karnes, H.T. Microfluidic immunoaffinity separations for bioanalysis. J. Chromatogr. B 2008, 866, 14-25. [CrossRef]

105. Moser, A.C.; Hage, D.S. Immunoaffinity chromatography: An introduction to applications and recent developments. Bioanalysis 2010, 2, 769-790. [CrossRef]

106. Prakash, S.; Karacor, M.B.; Banerjee, S. Surface modification in microsystems and nanosystems. Surf. Sci. Rep. 2009, 64, 233-254. [CrossRef]

107. Wu, Y.; Misra, S.; Karacor, M.B.; Prakash, S.; Shannon, M.A. Dynamic Response of AFM Cantilevers to Dissimilar Functionalized Silica Surfaces in Aqueous Electrolyte Solutions. Langmuir 2010, 26, 16963-16972. [CrossRef] [PubMed]

108. Lo, T.-W.; Zhu, Z.; Purcell, E.; Watza, D.; Wang, J.; Kang, Y.-T.; Jolly, S.; Nagrath, D.; Nagrath, S. Microfluidic device for high-throughput affinity-based isolation of extracellular vesicles. Lab A Chip 2020, 20, 1762-1770. [CrossRef] [PubMed]

109. Kang, H.; Kim, J.; Park, J. Methods to isolate extracellular vesicles for diagnosis. Micro Nano Syst. Lett. 2017, 5, 15. [CrossRef]

110. Sunkara, V.; Woo, H.-K.; Cho, Y.-K. Emerging techniques in the isolation and characterization of extracellular vesicles and their roles in cancer diagnostics and prognostics. Analyst 2016, 141, 371-381. [CrossRef] [PubMed]

111. Ribeiro-Samy, S.; Oliveira, M.I.; Pereira-Veiga, T.; Muinelo-Romay, L.; Carvalho, S.; Gaspar, J.; Freitas, P.P.; López-López, R.; Costa, C.; Diéquez, L. Fast and efficient microfluidic cell filter for isolation of circulating tumor cells from unprocessed whole blood of colorectal cancer patients. Sci. Rep. 2019, 9, 1-12. [CrossRef] [PubMed]

112. Doh, I.; Yoo, H.-i.; Cho, Y.-H.; Lee, J.; Kim, H.K.; Kim, J. Viable capture and release of cancer cells in human whole blood. Appl. Phys. Lett. 2012, 101, 043701. [CrossRef]

113. Zhang, P.; Bachman, H.; Ozcelik, A.; Huang, T.J. Acoustic Microfluidics. Annu. Rev. Anal. Chem. 2020, 13, 17-43. [CrossRef]

114. Li, P.; Huang, T.J. Applications of Acoustofluidics in Bioanalytical Chemistry. Anal. Chem. 2019, 91, 757-767. [CrossRef] [PubMed] 
115. Ding, X.; Li, P.; Lin, S.-C.S.; Stratton, Z.S.; Nama, N.; Guo, F.; Slotcavage, D.; Mao, X.; Shi, J.; Costanzo, F.; et al. Surface acoustic wave microfluidics. Lab A Chip 2013, 13, 3626-3649. [CrossRef]

116. Hahn, P.; Leibacher, I.; Baasch, T.; Dual, J. Numerical simulation of acoustofluidic manipulation by radiation forces and acoustic streaming for complex particles. Lab A Chip 2015, 15, 4302-4313. [CrossRef] [PubMed]

117. Wiklund, M.; Green, R.; Ohlin, M. Acoustofluidics 14: Applications of acoustic streaming in microfluidic devices. Lab A Chip 2012, 12, 2438-2451. [CrossRef] [PubMed]

118. Connacher, W.; Zhang, N.; Huang, A.; Mei, J.; Zhang, S.; Gopesh, T.; Friend, J. Micro/nano acoustofluidics: Materials, phenomena, design, devices, and applications. Lab A Chip 2018, 18, 1952-1996. [CrossRef] [PubMed]

119. Zhou, J.; Papautsky, I. Viscoelastic microfluidics: Progress and challenges. Microsyst. Nanoeng. 2020, 6, 113. [CrossRef] [PubMed]

120. Asghari, M.; Cao, X.; Mateescu, B.; van Leeuwen, D.; Aslan, M.K.; Stavrakis, S.; deMello, A.J. Oscillatory Viscoelastic Microfluidics for Efficient Focusing and Separation of Nanoscale Species. ACS Nano 2020, 14, 422-433. [CrossRef]

121. Zhou, J.; Kulasinghe, A.; Bogseth, A.; O’Byrne, K.; Punyadeera, C.; Papautsky, I. Isolation of circulating tumor cells in non-smallcell-lung-cancer patients using a multi-flow microfluidic channel. Microsyst. Nanoeng. 2019, 5, 8. [CrossRef] [PubMed]

122. Gossett, D.R.; Weaver, W.M.; Mach, A.J.; Hur, S.C.; Tse, H.T.K.; Lee, W.; Amini, H.; Di Carlo, D. Label-free cell separation and sorting in microfluidic systems. Anal. Bioanal. Chem. 2010, 397, 3249-3267. [CrossRef] [PubMed]

123. Lochab, V.; Prakash, S. Combined electrokinetic and shear flows control colloidal particle distribution across microchannel cross-sections. Soft Matter 2021, 17, 611-620. [CrossRef] [PubMed]

124. Lochab, V.; Yee, A.; Yoda, M.; Conlisk, A.T.; Prakash, S. Dynamics of colloidal particles in microchannels under combined pressure and electric potential gradients. Microfluid. Nanofluidics 2019, 23, 134. [CrossRef]

125. Dabros, T. Electrokinetic and Colloid Transport Phenomena: Jacob, H. Masliyah and Subir Bhattacharjee Publisher: WileyInterscience, 2006 ISBN: 0471799734. Can. J. Chem. Eng. 2006, 84, 729. [CrossRef]

126. Zhao, C.; Yang, C. Advances in electrokinetics and their applications in micro/nano fluidics. Microfluid. Nanofluidics 2012, 13, 179-203. [CrossRef]

127. Voldman, J. Electrical forces for microscale cell manipulation. Annu. Rev. Biomed. Eng. 2006, 8, 425-454. [CrossRef] [PubMed]

128. Ghosal, S.; Chen, Z. Electromigration dispersion in a capillary in the presence of electro-osmotic flow. J. Fluid Mech. 2012, 697, 436-454. [CrossRef]

129. Zhao, W.; Zhang, L.; Ye, Y.; Li, Y.; Luan, X.; Liu, J.; Cheng, J.; Zhao, Y.; Li, M.; Huang, C. Microsphere mediated exosome isolation and ultra-sensitive detection on a dielectrophoresis integrated microfluidic device. Analyst 2021, 146, 5962-5972. [CrossRef]

130. Pak Kin, W.; Tza-Huei, W.; Deval, J.H.; Chih-Ming, H. Electrokinetics in micro devices for biotechnology applications. IEEE/ASME Trans. Mechatron. 2004, 9, 366-376. [CrossRef]

131. Krishnan, R.; Sullivan, B.D.; Mifflin, R.L.; Esener, S.C.; Heller, M.J. Alternating current electrokinetic separation and detection of DNA nanoparticles in high-conductance solutions. Electrophoresis 2008, 29, 1765-1774. [CrossRef] [PubMed]

132. Cheng, I.F.; Chen, T.Y.; Chang, H.C. Electrokinetics-Based Microfluidic Technology for the Rapid Separation and Concentration of Bacteria/Cells/Biomolecules. Adv. Mater. Res. 2014, 911, 347-351. [CrossRef]

133. Diaz-Armas, G.G.; Cervantes-Gonzalez, A.P.; Martinez-Duarte, R.; Perez-Gonzalez, V.H. Electrically driven microfluidic platforms for exosome manipulation and characterization. Electrophoresis 2021, 43, 327-339. [CrossRef] [PubMed]

134. Romero-Soto, F.O.; Polanco-Oliva, M.I.; Gallo-Villanueva, R.C.; Martinez-Chapa, S.O.; Perez-Gonzalez, V.H. A survey of electrokinetically-driven microfluidics for cancer cells manipulation. Electrophoresis 2021, 42, 605-625. [CrossRef] [PubMed]

135. Aïzel, K.; Fouillet, Y.; Pudda, C. Electropreconcentration of nanoparticles using a radial micro-nanofluidic device. J. Nanoparticle Res. 2014, 16, 2731. [CrossRef]

136. Lu, Y.; Liu, T.; Lamanda, A.C.; Sin, M.L.Y.; Gau, V.; Liao, J.C.; Wong, P.K. AC Electrokinetics of Physiological Fluids for Biomedical Applications. J. Lab. Autom. 2014, 20, 611-620. [CrossRef] [PubMed]

137. Dey, R.; Shaik, V.A.; Chakraborty, D.; Ghosal, S.; Chakraborty, S. AC Electric Field-Induced Trapping of Microparticles in Pinched Microconfinements. Langmuir 2015, 31, 5952-5961. [CrossRef] [PubMed]

138. Kato, K.; Kobayashi, M.; Hanamura, N.; Akagi, T.; Kosaka, N.; Ochiya, T.; Ichiki, T. Electrokinetic Evaluation of Individual Exosomes by On-Chip Microcapillary Electrophoresis with Laser Dark-Field Microscopy. Jpn. J. Appl. Phys. 2013, 52, 06GK10. [CrossRef]

139. Akagi, T.; Kato, K.; Hanamura, N.; Kobayashi, M.; Ichiki, T. Evaluation of desialylation effect on zeta potential of extracellular vesicles secreted from human prostate cancer cells by on-chip microcapillary electrophoresis. Jpn. J. Appl. Phys. 2014, 53, 06JL01. [CrossRef] 